\title{
北海道-本州直流幹線におけるがいし金具の 腐食に関する研究結果
}

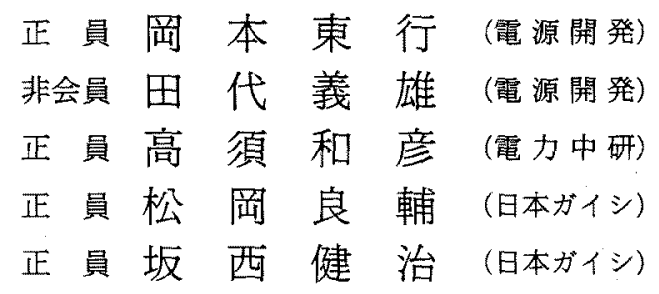

\section{Investigation of Corrosion of Insulator Hardware in the Hokkaido-Honshu DC Transmission Line}

Haruyuki Okamoto, Member, Norio Tashiro Non-member (Electric Power Development Co., Ltd.), Kazuhiko Takasu, Member (Central Research Institute of Electric Power Industry), Ryosuke Matsuoka, Member, Kenji Sakanishi, Member (NGK Insulators, Ltd.)

The Hokkaido-Honshu DC transmission line, the first DC transmission line in Japan, has been successfully operated for the past 11 years since its operation started in December, 1979 with $125 \mathrm{kV}$ and its operating voltage was increased to $250 \mathrm{kV}$ in June, 1980. This DC line, which interconnects the Hokkaido and Mainland of Japan, is located at a distance ranging from $0.5 \mathrm{~km}$ to $12 \mathrm{~km}$ from the seacoast.

Under such circumstances, the authors have been concerned about insulator contamination flashover and the corrosion of hardware, especially pin, due to the electrolysis.

Thus a series of periodical ESDD measurements and investigation of the insulator hardware corrosion have been conducted.

The investigation results show that the original design ESDD values are adequate and the effectiveness of zinc sleeve against the electrolytic corrosion of pin has been clarified. Reduction in weight of zinc sleeve is not only due to the electrolysis but also due to the natural corrosion in the corrosive atmosphere near the seacoast.

キーワード：直流送電線，がいし，電荷量，電食，亜鉛スリーブ，等価塩分付着密度

\section{1. まえがき}

北海道一本州直流幹線（以下，北一本直流幹線と略 記）は，我が国初の本格的直流送電線路であること， 架空線路が重污損地区を通過していることなどから， がいしの保守管理のため，等価塩分付着密度，表面漏 れ電流による電荷量，がいし金具の腐食などについて 継続的な調査が行われている。
特にがいし金具の腐食については周囲の雾囲気やが いし表面の污損に左右されると共に，直流課電に起因 する電食も心配される。がいしの合理的な保守管理を 行うには広範团な地区のがいし金具の腐食の実態を把 握しておく必要がある。このような観点から,北一本直 流幹線では毎年污損の厳しい臨海地区のがいしを中心 に, ピンの腐食, 亜鉛スリーブの減耗量の調查を実施し ている。本論文ではこれらの調查研究結果を報告する。 


\section{2. がいし金具の腐食の概念}

〈2・1〉 電 食 直流電圧が印加された懸垂が いしにおいて，がいし表面が污損湿潤すると，キャッ プピンの間を漏れ電流が流れ，電気分解の原理に従 って正極側の金具が溶出することとなる。ピン側が正 極課電の場合，ピンの大気露出部は，電食によりやせ 細って機械的強度が低下し，またセメント内部のピン は, 電食により腐食すると体積膨張し，磁器を押し割 る恐れがある。

ピン側が負極課電の場合には，キャップが電食を受 けることになるが，キャップの場合には，ピンに比べ 電流密度が小さいので，一般には問題とならない。し 加し海外の直流送電線において，キャップ下端面とが いし上面にほとんど間隙のない場合に，キャップ下端 部の腐食生成物の体積膨張により，ガラスがいしが破 損している例もある。

〈2・2〉自然腐食 がいし金具の腐食としては， 上述の電食以外に課電に無関係に進行する自然腐食が ある(1)。なお，課電されていない金属の自然腐食は金 属表面に絶緑性の酸化被膜が形成されると腐食の進行 は抑制されるが，課電されている場合には局部放電に よって酸化被膜が破壊されるのて，鹰食の進行の抑制 はあまり期待できない。

〈2・3〉亜鉛スリープの防食作用 亜鉛スリーブ は, 図 1 に示すように，電食の発生しやすいセメント と大気境界部に，ピン本体に密着して取付けられてい る。亜鉛はピン本体の材料である鋼よりも電気化学的 に陽極性であり，表面漏れ電流により，严鉛スリーブ
が選択的に電食を受け，鋼ピン本体の電食を防止しよ うとするものである。

亜鉛スリープ付きピンを使用したがいしは，北一本 直流幹線を初め世界各地の直流送電線で使用され，優 れた効果をあげている。

〈2・4〉直流課電がいしの破損例 直流課電がい しの破損例を表 1 に示す(2) (4)。重污損地区では，普 通ピンを用いたがいしは $6 \sim 10$ 年程度でピンの腐食膨 張により破損している。亜鉛スリーブ付きピンを使用 したがいしが破損した例は、ニュージーランド $250 \mathrm{kV}$ 直流送電線の重污損地区のみである。当初，破損の原 因が，スリーブに用いた亜鉛に混入した鉛に起因する スリーブの粒界腐食による体積膨張であるとして，純 重鉛スりーブ付きがいしに取替えられたが，純亜鉛ス リーブ付きがいしについても，一部重污損地区でセメ ント内部のピンの腐食膨張により破損が発生した。他 の地域では良好な性能を示す亜鉛スリーブ付きがいし

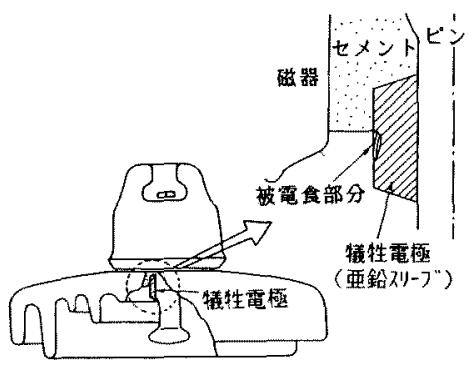

図 1 犠牲電極取付讨図

Fig. 1. Insulator with sacrificial electrode.

表 1 直流課電がいしの電食による破損例

Table 1. Examples of damaged DC insulators caused by electrolytic corrosion.

\begin{tabular}{|c|c|c|c|c|c|c|}
\hline \multirow[b]{2}{*}{ 使用場所 } & \multirow[b]{2}{*}{ がいし } & \multicolumn{3}{|c|}{ 使用条件 } & \multirow{2}{*}{$\begin{array}{l}\text { 蛙鉛又りープの } \\
\text { 有 無 }\end{array}$} & \multirow[b]{2}{*}{ 破 損 原 因 } \\
\hline & & $\begin{array}{c}\text { 使用期間 } \\
\text { (時間) }\end{array}$ & $\begin{array}{l}\text { 分担笔在 } \\
(\mathrm{kV} / \text { 個 })\end{array}$ & っり形 & & \\
\hline \multirow{2}{*}{ 笔研武山 } & 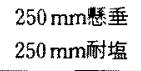 & $\begin{array}{l}5 \text { 年 } 9 \text { 筬月 } \\
(37.294 \mathrm{~h})\end{array}$ & $\begin{array}{l}>+17 \\
>+21\end{array}$ & 耐張 & 無 & \multirow{3}{*}{ 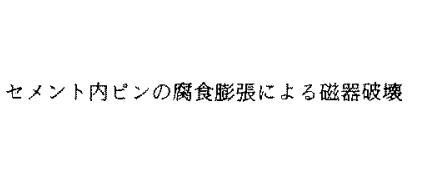 } \\
\hline & $\begin{array}{l}250 \mathrm{~mm} \text { 懸垂 } \\
250 \mathrm{~mm} \text { 酎塩 }\end{array}$ & $\begin{array}{l}7 \text { 年 } 7 \text { 韁月 } \\
(47,132 \mathrm{~h})\end{array}$ & $\begin{array}{l}>+17 \\
>+21\end{array}$ & 慗垂 & 無 & \\
\hline$J R$ 宇部 & $180 \mathrm{~mm}$ 㥎垂 & 10年 & $1.5 / 2$ & 慗垂 & 無 & \\
\hline \multirow{2}{*}{ ニュージーランド } & 旧䂆塩がいし & 6 年以降 & $\begin{array}{l}8.3 \\
8.9\end{array}$ & 墅垂 & $\begin{array}{c}\text { 育 } \\
\text { (垔鉛台金) } \\
\end{array}$ & 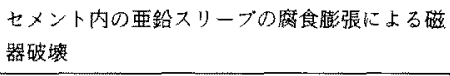 \\
\hline & $250 \mathrm{~mm}$ 酎塩 & 6 年以降 & 8.9 & 紫垂 & $\begin{array}{c}\text { 有 } \\
\text { (縂严鉛) }\end{array}$ & 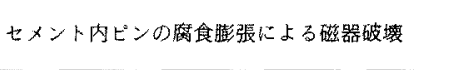 \\
\hline \multirow{2}{*}{ 電研武山 } & \multirow{2}{*}{$\begin{array}{l}\text { 下ひだSP } \\
(\mathrm{SP}-850 \mathrm{H})\end{array}$} & $\begin{array}{l}14 \text { 年 } \\
(95,500 \mathrm{~h}) \\
\end{array}$ & 62.5 & 垂直 & 無 & \multirow{2}{*}{ 金具内面の腐食膨張による金具破壞 } \\
\hline & & $\begin{array}{l}11 \text { 年 } \\
(67,600 \mathrm{~h})\end{array}$ & $\begin{array}{l}80 \text { ( } 9 \text { 年) } \\
62 \text { ( } 2 \text { 年) }\end{array}$ & 垂植 & 無 & \\
\hline
\end{tabular}


が破損寸るのは，この地区の污損が非常に澉しいうえ 頻繁に高湿度（霧)にさらされるため，セメント内部が 常に湿潤した状態となり，漏れ電流がセメント内部を 通ってセメント内部のピン本体に流れ込み, 要鉛スリ 一ブがあるにもかかわらず，セメント内部のピン本体 が腐食し体積賠張するためと考えられる。このような 特殊環境条件用として, セメント内の亜鉛スリーブと ピンの表面に絶縁コーティングを施し，ピンの腐食を 防止する対策を考案し，現在実フィールドでがいしの 一般的性能と併せてその効果を検証している(3)。実験 室の評価では, 長期性能を含めたがいしの機械的性能 は標準がいしと同等であることを確認済みである。

なお電研武山で, 11 年間と 14 年間直流課電された $\mathrm{SP}$ がいしの金具にクラックが発見された。原因は電 食により金具内面にさびが発生し，体積膨張により金 具自身にクラックが生じたものである。

\section{3. 北-本直流幹線}

北-本直流幹線は，図 2 に示すように北海道函館変 換所と本州上北変換所間約 $170 \mathrm{~km}$ を直流 $250 \mathrm{kV}$ て

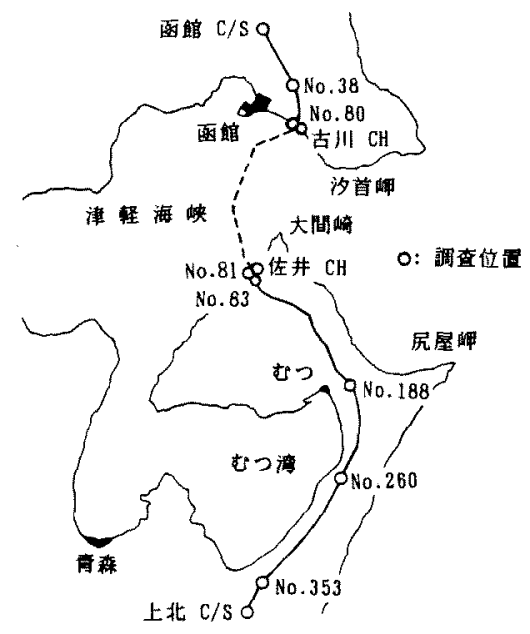

図 2 北-本直流幹線経路図

Fig. 2. Route of Hokkaido-Honshu HVDC line.

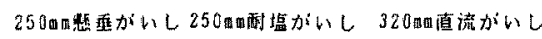
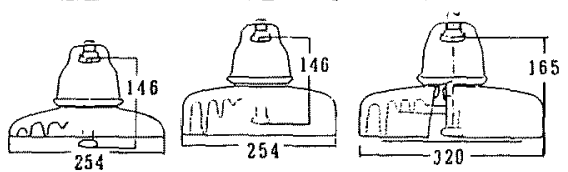

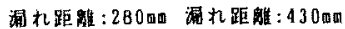

通九距趽: $510 \mathrm{~mm}$

図 3 北-本直流幹線使用がいし

Fig. 3. Insulators used in HokkaidoHonshu HVDC line.
連系するもので，架空送電線約 $130 \mathrm{~km}$, 海底ケーブ ル約 $40 \mathrm{~km} に よ り$ 構成されている。送電線は片極で 運転されており，極性反転によって潮流制御を行って いる。運開は昭和 54 年 12 月であり, 平成元年 10 月 までの課電時間は䋈計 17,883 時間で, 課電率は約 $21 \%$ あるる。

送電線のがいしは軽污損地区が 1 連あたり $250 \mathrm{~mm}$

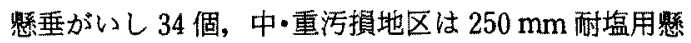
垂がいし 32 個および 37 個, 䠰海地区は $320 \mathrm{~mm}$ 直流 がいし 34 個である。これらのがいしはすべて亜鉛ス リーブ付きである。

がいしの形状，寸法は図 3 に示すとおりである。

\section{4. 調查項目, 調查対象場所}

〈4・1〉等価塩分付着密度の調查 図 2 に示す各 地点の鉄塔にパイロットがいしをつり下げ，無課電状 態で年間を通して 3 箅月ごとに，冬季は 1 篃月ごとに がいし表面の污損度の測定を実施している。測定対象 がいしは北-本直流幹線で使用されているがいしと $250 \mathrm{~mm}$ 恝垂がいしの 2 種類である。

〈4・2〉電荷量の測定函館, 上北両変換所招上 び古川ケーブル立上り部のNo. 80 鉄塔で実使用され ているがいしについて，がいし連の接地側に電荷量計 を挿入し, 漏れ電流による電荷量を連続測定してい る。なお函館变換所, No. 80 鉄塔では正負両極の電 荷量を, 上北変換所では負極のみの電荷量を測定して いる。

〈4・3〉亜鉛スリーブ減耗量の調查 毎年 1 回寒 線路で使用しているがいしを撤去し，亜鉛スリープの 減耗量を測定している。スリーブの減耗量は,がいし を解体の後ピンスリーブ部を円周方向に 4 分割し, 図 9 に示すような裁断面の拡大写真より減耗面積を測定 し, 計算により求めている。調查の対象は主として臨 海地区の㷂垂鉄塔 No. 80 と No. 83，扔よび耐張鉄塔 No.81である。このほかの地区のがいしについても， 適宜垔鉛スリーブの減耗量を調查している。

\section{5、等価塩分付着密度の調查結果}

3 箇月ごとの定期測定結果の $50 \%$ 値および実測最 大等価塩分付着密度を図 4 亿示す。

実測最大值は，3 笝月ごとの定期測定值の $50 \%$ 值 に対しては，3.0〜6.5倍となっているが，設計塩分 付着密度に対しては $1 / 2 \sim 1 / 3$ となっている所が多い。

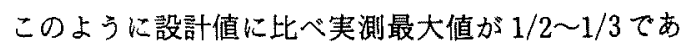
るのは, 調查期間中に大形風台風の襲来がなかったた めである。250 mm 䇣垂がいしに対する $250 \mathrm{~mm}$ 耐塩 
表 2 北-本直流幹線におけるがいし表面漏九電荷量測定結果

Table 2. Measurement results of quantity of electricity due to the leakage current on the insulator surface.

\begin{tabular}{|c|c|c|c|c|c|c|c|c|}
\hline 測定地点 & 使用がいし & $\begin{array}{l}\text { 分担電质 } \\
(\mathrm{kV} / \text { 個) }\end{array}$ & $\begin{array}{c}\mathrm{ESDD}^{*} \\
\left(\mathrm{mg} / \mathrm{cm}^{2}\right)\end{array}$ & 測定極性 & 湖定期間 & $\begin{array}{c}\text { 課電時間 } \\
\text { (h) }\end{array}$ & $\begin{array}{c}\text { 军測電荷暂 } \\
\text { (C) }\end{array}$ & 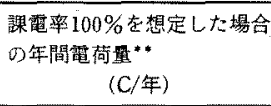 \\
\hline \multirow{2}{*}{ 㖤期㕠換所 } & \multirow{2}{*}{$250 \mathrm{~mm}$ 䣄垂 } & \multirow{2}{*}{7.4} & \multirow{2}{*}{0.008} & + & $86.12 \sim 89.10$ & 6,702 & 117 & 153 \\
\hline & & & & - & $80.10 \sim 89.10$ & 3,990 & 77 & 169 \\
\hline 上北変換所 & $250 \mathrm{~mm}$ 耐塩 & 6.8 & 0.002 & - & $\bar{\prime} 80.10 \sim 85.2$ & 3,890 & 298 & 671 \\
\hline \multirow{2}{*}{ No.80銑蛤 } & \multirow{2}{*}{$320 \mathrm{~mm}$ 直流 } & \multirow{2}{*}{7.4} & \multirow{2}{*}{0.014} & + & $80.10 \sim ' 89.10$ & 12,710 & 1,489 & 1,026 \\
\hline & & & & - & $80.10 \sim ' 89.10$ & 4,046 & 464 & 1,005 \\
\hline \multirow{2}{*}{ 電研武山 } & $320 \mathrm{~mm}$ 直流 & 11.4 & 0.026 & + & '81. $1 \sim ' 84,12$ & 28,796 & 1,919 & $370 \sim 750$ \\
\hline & $250 \mathrm{~mm}$ 照型 & 10.0 & 0.025 & + & '81. $1 \sim 84.12$ & 28,796 & 1.772 & $400 \sim 750$ \\
\hline \multirow{2}{*}{ 電研米沢 } & \multirow{2}{*}{$250 \mathrm{~mm}$ 㗭 } & 11.2 & 0.008 & - & $81.12 \sim 83.4$ & 7,950 & 175 & $150 \sim 210$ \\
\hline & & $13.3 \sim 14$ & 0.008 & - & $83.5 \sim 87.3$ & 25,911 & 637 & $200 \sim 250$ \\
\hline
\end{tabular}

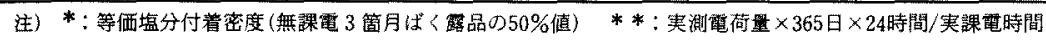

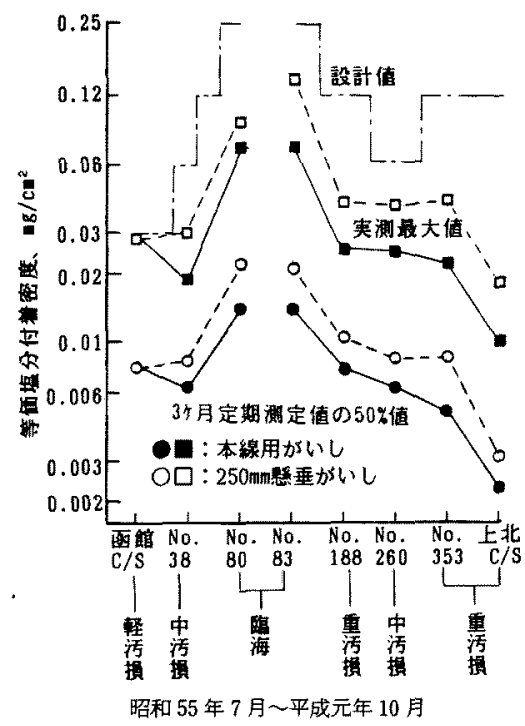

困 4 等価塩分付着密度の測定結果 (無課電がいし下面)

Fig. 4. Measurement results of ESDD.

用馝垂がいし， $320 \mathrm{~mm}$ 直流がいしの等価塩分付着密 度比は $0.5 \sim 0.8$ であった。これはここれまでに他所 で測定されている結果とほほ同等の比率である(5)。

3 简月ごとの定期測定值の $50 \%$ 値に対する冬季 1 籄月ごとの等価塩分付着密度の $50 \%$ 值の比を図 5 に 示す。

函館変換所以外では冬季 1 䈏月ばく露の等価塩分付 着密度は，ばく露期間が短いにもかかからず 3 箇月ば く露の等価塩分付着密度より大きくなっている。これ は，冬季に強い季節風が吹くためである。

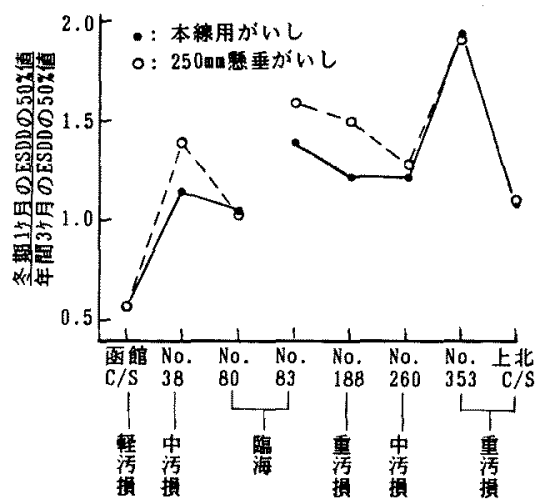

図 5 冬期 1 䇢月ばく露と年間 3 简月ばく露 がいしの等価塩分付着密度の比較

Fig. 5. Ratio of ESDD of one month exposure insulator in winter to that of three month exposure insulator in all seasons.

\section{6. がいし表面漏れ電荷量測定結果}

平成元年 10 月までのがいし表面漏れ電荷量測定結 果を表 2 に示す。表には参考のため電研武山(6), 電研 米沢(7)における測定結果も併記した。

函館変換所においてもNo.80 鉄塔においても課電 率を $100 \%$ と想定した場合の正, 負両極性の年間電荷 量はほほ同等であり，極性による電荷量の差は見られ ない。なお，電研武山の調査でも印加電圧の極性によ る電荷量の差は見られていない(6)。

年間電荷量は軽污損地区の函館では $150 \mathrm{C}$ 程度, 臨 海地区の No. 80 鉄塔では, $1,000 \mathrm{C}$ 程度と測定地点に よりかなり異なっている。また臨海地区の No. 80 鉄 
塔と電研武山を比較すると, 前者の等価塩分付着密 度，がいしの平均分担電圧は，ともに後者より小さい にもかかわらず電荷量は前者のほうが大きくなってい る。これは電研武山での電荷量の解析結果 ${ }^{(6)}$ にも示 されているように，電荷量は等洒塩分付着密度のほか に降雨量, 降雨時間, 高湿度の時間など湿潤条件の影 響も強く受けるためと考えられる。

\section{7. 亜鉛スリープ減耗量測定結果}

〈7・1〉使用場所と亜鉛スリーブ減耗量 使用期 間 $2 \sim 4$ 年の北-本直流幹線各所の眯垂づりがいしの 亜鉛スリーブ減耗量測定結果を，使用期間 1 年あたり の減耗垩で整理したものを龱6に示す。

咞鉛スリーブ減耗量は，同一場所でも使用期間によ って大きくばらついているが，臨海地区に位置する No. $80, N o .83$ 鉄塔の西鉛スリーブの減耗量はその 他の地区の減耗量に比べ格段に多くなっている。

これは污損環境の策しい臨海地区では，がいし污損 と䶃潤条件によって決まる電荷量による電食，〈7・3〉 節で述べる課電の有無とは無関係な, 自然腐食による 減耗量の両者が他地区に比べて大きいためと考えら れる。

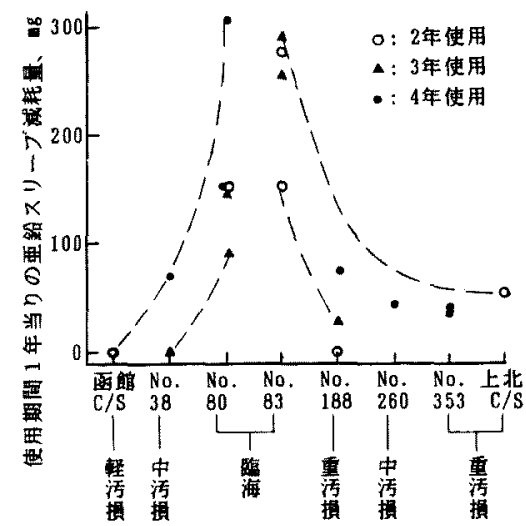

図 6 北-本直流幹線各所の亜鉛スリーブ 減耗量

Fig. 6. Reduction in weight of zinc sleeve.
〈7・2〉使用期間と減耗量 亜鉛スリーブの減耗 量を継続的に測定している臨海地区のNo. 80, No. 83,No. 81 鉄塔における使用期間と亚鉛スリーブ減 耗量の関係を図 7 に示す。

がいしが懸垂づりのNo. 80，No.83 鉄塔における 亜鉛スリーブ減耗量は年平均 160〜290 $\mathrm{mg}$ 程度, 耐 張づりの No. 81 鉄塔では 55〜130 mg 程度であった。 ただし，この值は正極性電圧の課電率が約 $11 \%$ にお ける減耗量であり，課電率が上がれば年間の減耗量は 更に大きくなると考えられる。耐張づりがいしの減耗 量は䀣づりがいしの 40\%程度となっている。これ は，耐張づりのほうが懸垂づりより雨洗効果が良いこ と，がいし表面が乾焻しやすいことなどが影響してい ると考えられる。なお電研武山において，平均分担電 圧 $21 \sim 36 \mathrm{kV} /$ 個, 課電率約 $80 \%$ て 14 年間妝垂づり でばく簬した $320 \mathrm{~mm}$ 直流がいしの亜鉛スリーブの年 平均減耗量は $680 \mathrm{mg}$ 程度である(6)。

〈7-3〉電食量と自然腐食量使用期間約 8 年の No. 80 鉄塔におけるがいしの西鉛スリーブ減耗量と 電荷量の関係を哀 3 に示す。

垔鉛スりーブの减耗量がすべて電食によるとして計 算した年平均等価電荷量と実測電荷量の差は, 自然腐 食による減耗量で，その等価電荷量は 480〜 $570 \mathrm{C} て ゙$ ある。一方,無課電がいしの亜鉛スリーブの減耗量は自

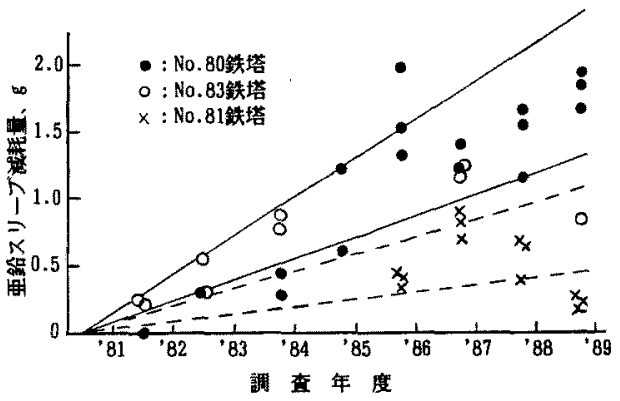

図 7 使用期間と要鉛スリーブ減耗量 (臨海地区)

Fig. 7. Relation between duration of operation and reduction in weight of zinc sleeve.

表 3 亜鉛スリープの減耗量と電荷量

Table 3 . Reduction in weight of zinc sleeve and quantity of electricity.

\begin{tabular}{|c|c|c|c|c|c|c|c|c|c|}
\hline 使用敀所 & 使用がいし & $\begin{array}{l}\text { がいしの } \\
\text { つり形 }\end{array}$ & $\begin{array}{c}\text { 平均分担電圧 } \\
(\mathrm{kV} / \text { 個 })\end{array}$ & $\begin{array}{c}\text { 使用期間 } \\
\text { (年) }\end{array}$ & $\begin{array}{c}\text { 正極電压 } \\
\text { 課 饂 } \\
(\%)\end{array}$ & $\begin{array}{l}\text { スリーブ } \\
\text { 滅耗 悬 } \\
(\mathrm{mg} / \text { 年) }\end{array}$ & $\begin{array}{c}\text { スリーブ減耗量から } \\
\text { 計算した年平均 } \\
\text { 等価電荷量 } A \\
\text { (C/年) }\end{array}$ & $\begin{array}{c}\text { 年平均実測 } \\
\text { 笔荷量 } B \\
\text { (C/年) }\end{array}$ & 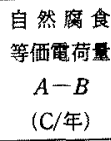 \\
\hline \multirow{2}{*}{ No. 80 鉄塔 } & \multirow{2}{*}{$320 \mathrm{~mm}$ 直流 } & \multirow{2}{*}{ 檍垂 } & 7.4 & 8.3 & 11 & $200 \sim 230$ & $590 \sim 680$ & 110 & $480 \sim 570$ \\
\hline & & & 無課電 & 8.3 & - & 185 & 540 & 0 & 540 \\
\hline
\end{tabular}


表 4 ピン付着污損物の化学分析結果(約 8 年使用後)

Table 4. Results of chemical analysis of contaminants deposited on pin.

\begin{tabular}{|c|c|c|c|c|c|c|c|c|}
\hline \multirow{2}{*}{\multicolumn{2}{|c|}{ 鉄塔 No. }} & \multicolumn{7}{|c|}{ 分 (wt \%) } \\
\hline & & \multirow{2}{*}{$\frac{\mathrm{ZnO}}{64.41}$} & \multirow{2}{*}{$\frac{\mathrm{Al}_{2} \mathrm{O}_{3}}{0.73}$} & \multirow{2}{*}{$\begin{array}{c}\mathrm{Fe}_{2} \mathrm{O}_{3} \\
0.56\end{array}$} & \multirow{2}{*}{$\frac{\mathrm{CaO}}{0.48}$} & \multirow{2}{*}{$\begin{array}{r}\mathrm{MgO} \\
0.80\end{array}$} & \multirow{2}{*}{$\begin{array}{l}\mathrm{Na}_{2} \mathrm{O} \\
2.04\end{array}$} & \multirow{2}{*}{$\begin{array}{c}\mathrm{SiO}_{2} \text { 他 } \\
30.98\end{array}$} \\
\hline הo & 課 電 品 & & & & & & & \\
\hline No. ou & 無課電品 & 62.95 & 0.77 & 0.61 & 0.43 & 0.74 & 1.96 & 32.54 \\
\hline No. 83 & 課 電 品 & 63.81 & 0.55 & 0.40 & 0.31 & 0.66 & 2.39 & 31.88 \\
\hline
\end{tabular}

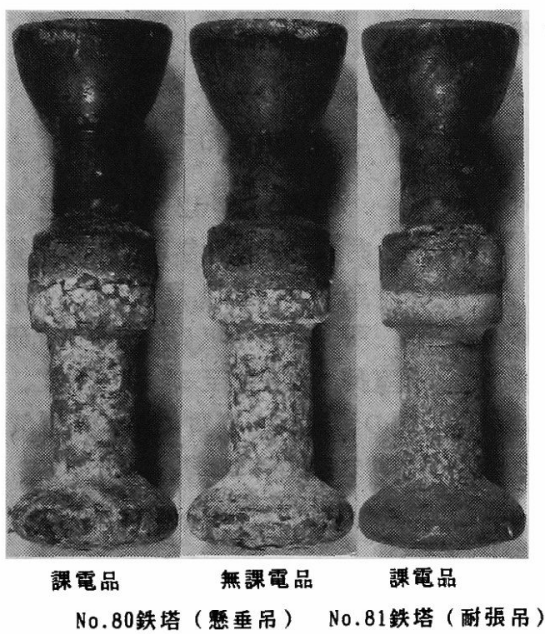

図 8 ピン外観写真 (約 8 年使用後)

Fig. 8. Outside view of pin (after 8 years operation).

然腐食のみによるもので，これより計算した 1 年あた

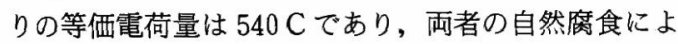
る等価電荷量はほほ一致している。なお, 電研武山の 1 年あたりの自然腐食等価電荷量は 850 950C 程 度(6) と計算されている。このように自然腐食量は測 定地点の環境条件により大きく異なり, 電荷量による 電食に比べて無視できない量であると言える。今後他 の地区においても長期にわたる調査が必要であろう。

$\langle 7 \cdot 4\rangle$ ピン解体結果北-本直流幹線で約 8 年間 使用したピンの代表的外観を図 8 に示す。臨海地区䯚 垂づりの No. 80 鉄塔におけるがいしのピンの大気露 出部は, 課電品, 無課電品とも白さび状の腐食生成物 でかなり厚く覆われている。これに対し, 同じ臨海地 区でも耐張づりの No. 81 鉄塔のがいしの白さび状腐 食生成物の量はNo.80 鉄塔に比べかなり少ない。こ れは先に述べたように, 耐張づりの場合には, 懸垂づ りに比べ雨洗効果が優れていること, 乾燥しやすいこ となどの影響によるものと考えられる。

No. 80, No. 83 鉄塔におけるピンの大気露出部の 白さび状腐食生成物の分析結果を表 4 に示す。成分比

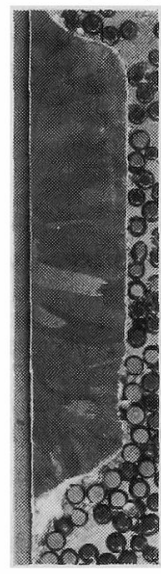

課電品

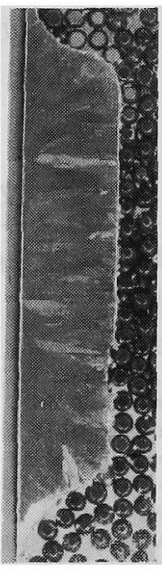

無課電品
図 9 亜鉛スリーブ半裁品の拡大写真 (No. 80 鉄塔で約 8 年使用後)

Fig. 9. Enlarged cross-sectional view of zinc sleeve (after 8 years operation at tower No. 80).

からみて白さびは亜鉛が溶出酸化したものと土砂など の污損物が混合したものであると考えられる。

No. 80 鉄塔の課電, 無課電がいしの亜鉛スリープ 半裁品の拡大写真を図 9 に示す。亜鉛スリーブの大気 露出部の腐食状況は課電品, 無課電品とも同じょうな 形態を示している。これは表 3 から明らかなように， 課電品の腐食の大部分が自然腐食によるためと考えら れる。

\section{8. むすび}

北-本直流幹線は運開以来 11 年間大きなトラブルも なく順調に運転されている。現在までの課電率はそれ ほど高くはないが, 今後飛躍的に高くなる見込みであ る。

現在までの調査ではピンの瘦せ細りもなく，亜鉛ス リーブは犠牲電極としての役割を十分果たしている。

亜鉛スリーブの減耗量は, 今後課電率が大きくなる と電荷量による電食によりかなり増えると考えられる が, 自然腐食による減耗量を含めて推定した場合でも 
臨海地区の亜鉛スリーブの寿命は今後更に 40 ～50 年 期待できる。また, セメント内部のピンの腐食に基づ く磁器の押し割りについても, 現在のところピンに腐 食の徴候は認められず，污損湿潤環境がニュージーラ ンドの一部地区ほどは敛しくないと思われるので心配 はないと考えられるが, 腐食が進み亜鉛めっき層が失 われ，赤さびが一旦発生すると腐食は急速に進行する 恐れもある。今後とも調査を継続し, 直流送電線にお けるがいしの保守管理の指針を確立していきたい。

(平成 3 年 1 月 22 日受付)

\section{文献}

（1）鬼頭・向坂・坂西：「悪垂碍子の電食と要鉛スリーブの防食 効果」, NGK レビュー, No. 43 (昭 57-10)

（2）渡辺・関・今野：「武山直流課電暴露実唫場におけるがいし ピンの電食状況の観察」, 電中研研報, 779001 (昭 55)

(3) L. M. Crabtree, K. J. Mackey, K. Kito, K. Naito, A. Watanabe \& T. Irie: "Studies on Electrolytic Corrosion of Hardware of DC Line Insulators", IEEE Trans. Power Apparatus Syst., PAS-104, No. 3 (1985)

（4）渡辺・谷口：「直流課電がいしの電食特性」, 電中研研報, W 86022 (昭 62)

（5） $500 \mathrm{kV}$ 送電実証試験研究(委): $500 \mathrm{kV}$ 送変電設備の実証試 験研究報告（昭 47）

（6）谷口・渡辺：「直流用馝垂碍子の電食」, 電中研研報, W 88005 (昭 63)

（7）高須・新藤・松田「内陸地域における直流課電がいしの污損 特性」, 同上, T 86077 (昭 62)

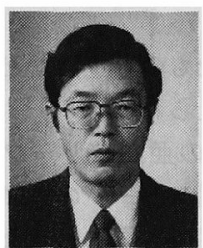

\section{岡 本 東 行 (正員)}

昭和 18 年 10 月 7 日生。 43 年 3 月東京工業大学電気工学科卒業。同 年 4 月電源開発(株) 入社, 56 年 10 月本四連系線事務所課長代理, 60 年 4 月工務部送電室課長代理, 60 年 10 月海外電力調 査会調査統計部主任研究員, 63 年 10 月工務部送電室 課長, 平成 3 年 3 月北本連系設備増設建設所所長代 理。CIGRE SC-22 Member

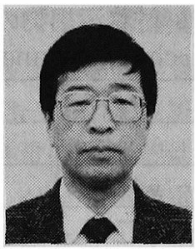

田 代 義 雄 (非会員)

昭和 18 年 2 月 14 日生。 36 年 3 月北海道立釧路工業高校電気科卒 業。同年 4 月電源開発 (株) 入社。 主として, 送電線の保守運営, 新増 設工事, 直流がいしの污損・放電現象業務に従事。現 在, 北本連系送電所所長代理。北本直流幹線の保守運 営業務に従事。

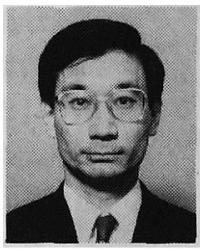

\section{高 須 和 彦（正員）}

昭和 21 年 12 月 17 日生。 45 年 3 月東京工業大学理工学部電気工学科 卒業。同年 4 月電力中央研究所入 所。平成元年 7 月同所狛江研究所送 配電部放電研究室長, 現在に至る。主として, 送変電 設備のがいし類の污損および雪に対する電気絶縁性 能，絶緑設計に関する研究に従事。

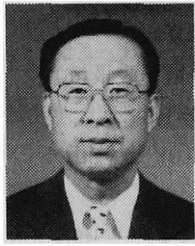

\section{松岡 良 輔 (正員)}

昭和 16 年 4 月 15 日生。 41 年 3 月名古屋大学大学院工学研究科修士 課程修了。同年 4 月日本碍子(株) 入 社。主として, がいしの污損特性に 関する研究に従事。現在, 超高圧研究所所長代理。 IEEE Senior Member，日本沙漠学会会員。

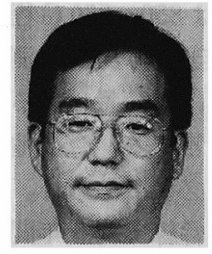

に従事。

\section{坂 西 健 治 (正員)}

昭和 18 年 9 月 15 日生。 37 年 3 月県立岐阜工業高校電気科卒業。同 年 4 月日本碍子(株) 入社。主とし て,がいしの污損特性に関する研究 